\title{
Prevalence of abnormal serum sodium and potassium concentration in paediatric new onset type 1 diabetes with ketoacidosis: A retrospective study from two Nigerian 'Teaching Hospitals
}

Alphonsus N. Onyiriuka, ${ }^{1}$ Elizabeth E. Oyenusi ${ }^{2}$

${ }^{1}$ Endocrinology and Metabolism Unit, Department of Child Health, University of Benin Teaching Hospital, PMB 1111, Benin City, Nigeria.

${ }^{2}$ Endocrinology and Metabolism Unit, Department of Paediatrics, Lagos University Teaching Hospital, PMB 12003, Lagos, Nigeria.

\section{Abstract}

Background/Aim: Community-acquired electrolyte disorders have been associated with poor prognosis following hospitalization and treatment for various illnesses. The aim of the study was to estimate the prevalence of abnormalities of serum sodium and potassium concentrations in patients with new-onset type 1 diabetes with ketoacidosis at presentation in the paediatric emergency departments of two Nigerian teaching hospitals.

Method: A retrospective medical records review was performed on all paediatric patients with new-onset type 1 diabetes complicated by ketoacidosis seen in two Nigerian hospitals (University of Benin Teaching Hospital and Lagos University Teaching Hospital) over a period of 5 years. Information obtained included age at diagnosis, gender, presenting complaints and outcome (dead or alive). Data on serum electrolyte concentrations (sodium, potassium, chloride, bicarbonate) as well as blood glucose before initiation of fluid resuscitation and insulin therapy were extracted. The anion gap and effective osmolality were computed.

Results: Overall, 25(53.2\%; 95\% Confidence interval, CI= 38.9-67.5) of the 47 patients had abnormalities in serum sodium, potassium or a combination of both. With regard to serum sodium, isolated abnormalities were found in $14(29.8 \%$; $95 \% \mathrm{CI}=16.7-42.9)$ of 47 patients. Hyponatremia occurred in $25.5 \%(95 \% \mathrm{CI}=19.1-31.9)$ and hypernatremia occurred in $2.1 \%(95 \% \mathrm{CI}=0.01-4.2)$. Of the 47 patients, $10(21.3 \%$; $95 \% \mathrm{CI}=15.3-27.3)$ had isolated serum potassium abnormalities. The frequency of hypokalemia and hyperkaliemia were $8.5 \%(95 \% \mathrm{CI}=4.4-12.6)$ and $10.6 \%(95 \% \mathrm{CI}=6.6-15.1)$, respectively. The hypokalemia was severe $(<2.5 \mathrm{mmol} / \mathrm{L})$ in $2.1 \%$ of cases. The frequency of combined hyponatremia and hypokalemia was $2.1 \%$. The mean anion gap was $18.6 \pm 0.6(95 \% \mathrm{CI}=18.4-18.8)$. The mean time for resolution of ketoacidosis was $2.8 \pm 0.6$ days $(95 \% \mathrm{CI}=2.6-3.0)$. Five $(10.9 \%)$ of the 47 patients were toddlers ( 1 to 3 years old). Polyuria, weakness and anorexia were the key presenting complaints in toddlers with DKA. Of the 28 patients from UBTH, one (3.4\%) died and the patient had severe mixed electrolyte disturbances (hyponatremia, hypokalemia and acidosis).

Conclusion: At point of hospitalization for paediatric new-onset diabetes with ketoacidosis, disturbances in serum sodium and potassium concentrations were common. Polyuria, weakness and anorexia were the key presenting complaints in toddlers with DKA.

Key words: Children, diabetic ketoacidosis, hyponatremia, hypernatremia, hypokalemia, hyperkalemia, toddlers.

DOI: http://doi.org/10.4038/sjdem.v8i1.7349

Received: 29 August $2017 \quad$ Accepted revised version: 18 September $2107 \quad$ Published: $9^{\text {th }}$ April 2018

Correspondence e-mail: alpndiony@yahoo.com

This is an open-access article distributed under the terms of the Creative Commons Attribution 4.0 International License, which permits unrestricted use, distribution and reproduction in any medium provided the original author and source are credited 


\section{Introduction}

Serum electrolytes play an important role in many physiologic and metabolic processes in the body. In the paediatric age group, community-acquired electrolyte disorders have received very little attention despite its potential in influencing prognosis (1). Among acutely ill children and adolescents, alterations in serum sodium and potassium concentrations are common, leading to increased morbidity and mortality (2). The American Diabetes Association (ADA) and the International Society for Pediatric and Adolescent Diabetes (ISPAD) consensus statements for managing diabetic ketoacidosis (DKA) recommend determining the serum potassium concentration prior to commencement of insulin therapy $(3,4)$. Such a recommendation is aimed at preventing iatrogenic morbidity and mortality associated with profound hypokalemia which may potentially complicate insulin therapy.

DKA is characterized by hyperglycemia, ketonemia (ketonuria) and metabolic acidosis (with elevated anion gap). In patients with DKA, serum sodium concentration is variable, reflecting the balance between the hyperglycemia-induced movement of water from intracellular to extracellular compartment that lowers serum sodium concentration by dilution and the glycosuria-induced osmotic diuresis which tends to elevate the serum sodium concentration (5).

In addition to this effect of hyperosmolality, insulin is known to stimulate the activity of sodium-potassium ATPase $(\mathrm{Na}+/ \mathrm{K}+$-pump) whose activity extrudes sodium from cells in exchange of potassium at a ratio of $3: 2$, respectively (6). The resultant effect is alteration in the distribution of sodium and potassium in the intra- and extracellular fluid spaces in conditions of insulin insufficiency. In this regard, Beukhof et al reported that independent of hyperglycemia, diabetes mellitus per se is associated with hyponatremia (7). In the presence of hyperglycemia, an elevated or normal serum sodium concentrations indicate a clinically significant deficit in total body water (8). The report of one study suggested that high serum sodium and glucose levels represent the most important determinants for the occurrence of rhabdomyolysis (9), a known rare complication of DKA $(4,10)$. In a study in USA involving children aged below 17 years with DKA, 33\% of the patients had hypernatremia (11). In addition, the authors concluded that there is increased likelihood of children with newonset diabetes presenting with hypernatremia (11).
Although it is estimated that a total body potassium deficit of $3-6 \mathrm{mmol} / \mathrm{kg}$ occurs at presentation of DKA, pretreatment serum potassium levels are usually normal due to the intracellular shift of potassium that occurs with metabolic acidosis and insulin deficiency (10). In this regard, hypokalemia occurs only in $5-10 \%$ of patients at presentation of DKA but very rarely is the concentration less than $2.5 \mathrm{mmol} / \mathrm{L}(12,13)$. The principal factor responsible for DKA-associated potassium depletion is increased renal losses due to the osmotic diuresis and ketoacid anion excretion (10). In addition, insulin plays a major role in mediating muscle potassium uptake to control the plasma potassium concentration $(14,15)$ via regulation of $\mathrm{Na}+/ \mathrm{K}+$-ATPase activity (6). Davis et al in Colorado, USA reported a case of an 8-year-old girl with profound hypokalemia $(1.3 \mathrm{mmol} / \mathrm{L})$ accompanied by cardiac dysrhythmia at presentation of DKA (15). In that study (15) insulin infusion was delayed until after serum potassium has risen above $2.5 \mathrm{mmol} / \mathrm{L}$ with treatment, as recommended by ISPAD (4). A similar approach has been recommended by Murthy et al (16).

This mode of management was possible because the physician had knowledge of the serum potassium level at point of admission. Such knowledge prevents iatrogenic morbidity and mortality with regard to hypokalemia (14). In a Pakistani retrospective study involving children less than 15 years old, the prevalence of hypokalemia was $8.0 \%$ (17). Despite low total body potassium, severe hyperkalemia may be associated with DKA as a result of deficit in body fluid, mainly caused by osmotic diuresis, and diminished renal function (18). As therapy is begun, serum potassium declines, sometimes precipitously due to continued urinary loss of potassium, dilution of extracellular fluid, correction of acidosis and administered insulin causing re-entry of potassium into the cells (18). Profound hyper- or hypokalemia, even if transient, could be dangerous or prove fatal (19). Some studies have shown that physiologically, significant racial differences exist in sodium and potassium homeostasis $(20,21)$. To the best of our knowledge, there is no published Nigerian study on details of serum sodium and potassium profiles of children and adolescents with new-onset diabetes complicated by ketoacidosis.

The purpose of the study was to estimate the prevalence of abnormalities of serum sodium and potassium concentrations in patients with new-onset type 1 diabetes mellitus with ketoacidosis at presentation in the paediatric emergency departments of two Nigerian teaching hospitals. 


\section{Materials and Methods}

In this retrospective study, the medical charts of all children and adolescents with newly diagnosed type 1 diabetes complicated by DKA who presented at the paediatric emergency departments of two Nigerian hospitals namely, University of Benin Teaching Hospital (UBTH) and Lagos University Teaching Hospital (LUTH) over a 5-year-peroid (1st January, 2012 to 31st December, 2016) were retrieved and audited. The Health Research and Ethics Committee of LUTH approved the study and waived the requirement for informed consent. Diabetic ketoacidosis was diagnosed based on the presence of hyperglycemia (blood glucose $>11.1 \mathrm{mmol} / \mathrm{L}$ or $200 \mathrm{mg} / \mathrm{dl}$ ), ketonuria and metabolic acidosis (serum bicarbonate $<15 \mathrm{mmol} / \mathrm{L}$ ) (4). These patients were first admitted into the paediatric emergency departments for stabilization and were subsequently transferred to the wards for continuation of management.

The detailed evaluation of each patient at presentation included measurement of the following biochemical parameters blood glucose, serum electrolytes, full blood count, serum creatinine and urine ketones. Serum sodium and potassium concentrations were estimated by flame photometer. Hourly monitoring of vital signs, neurologic status and blood glucose were performed and recorded. The ketoacidosis was considered to have resolved if serum bicarbonate rose above $15 \mathrm{mmol} / \mathrm{L}$ with a normal anion gap and stabilization of the patient's clinical condition (presence of normal vital signs and absence of vomiting). Additional information obtained from the case files included age, gender, time of resolution of DKA and final outcome (dead or alive). Effective osmolality was calculated, using the formula: Effective osmolality $=[2 \mathrm{x}$ (serum sodium) + (blood glucose in $\mathrm{mmol} / \mathrm{L})]$. Anion gap was calculated using the formula: Anion gap $=[$ Serum sodium - (Serum chloride + serum bicarbonate)] (4).

\section{Definition of terms:}

Hyponatremia $=$ serum sodium below $135 \mathrm{mmol} / \mathrm{L}$; severe hyponatremia = serum sodium below $120 \mathrm{mmol} / \mathrm{L}$; hypernatremia $=$ serum sodium above $150 \mathrm{mmol} / \mathrm{L}$; hypokalemia $=$ serum potassium below $3.5 \mathrm{mmol} / \mathrm{L}$; severe hypokalemia $=$ serum potassium below $2.5 \mathrm{mmol} / \mathrm{L}$; hyperkalemia $=$ serum potassium above $5.5 \mathrm{mmol} / \mathrm{L}$.

\section{Data Analysis}

The data were collected and entered into an Excel spread sheet. Accuracy of the data entered was double checked. Data were analyzed, using Microsoft Excel and SPSS (Statistical Package for Social Sciences) version 20.0. Descriptive statistics such as frequencies, means, standard deviations were used in describing all the variables. Confidence intervals, frequency distribution, percentages and ratios were calculated. Student's t-test was used in ascertaining the significance of difference between two means with $\mathrm{p}$-value set at $<0.05$.

\section{Results}

A total of 53 case files of the relevant patients were available but six were excluded because of incomplete information, leaving $47(88.7 \%)$ which constituted the study population. Of the 47 patients, 28 (59.6\%) were from UBTH and 19 (40.4\%) were from LUTH, giving a ratio of 1.5:1. As shown in Table 1 , majority of the patients were above 10 years old and there were more girls than boys (female to male ratio 1.4:1). Five (10.9\%) of the 47 patients were toddlers. Among these toddlers, the presenting complaints were polyuria (defined by excessively wet cloth napkins/diapers/ increased frequency of change of cloth napkins/diapers) (100.0\%), weakness $(100.0 \%)$, anorexia $(80.0 \%)$, breathlessness $(60.0 \%)$, vomiting $(60.0 \%)$ and lethargy $(60.0 \%)$. All the toddlers had obvious signs of dehydration at presentation. Overall, a combination of polyuria and polydipsia was the leading presenting complaints (Table 1). The mean $\mathrm{HbA} 1 \mathrm{C}$ was $11.4 \pm 2.3 \%$. There was no gender difference in mean blood glucose concentrations, being $27.7 \mathrm{mmol} / \mathrm{L}$ in each of the sexes. Overall, 25(53.2\%; 95\% Confidence interval, $\mathrm{CI}=38.9-67.5)$ of the 47 patients had abnormalities in serum sodium, potassium or a combination of both. Table 2 showed that the mean serum sodium was lowest in children aged below 5 years. With regard to serum sodium, Table 3 showed that isolated abnormalities were found in $14(29.8 \%$; 95\% $\mathrm{CI}=16.7-42.9)$ of the 47 patients. Isolated hyponatremia and hypernatremia occurred in $25.5 \%(95 \% \mathrm{CI}=19.1-31.9)$ and $2.1 \%(95 \% \mathrm{CI}=0.01-4.2)$ of the patients, respectively. Of the 47 patients, $10(21.3 \%$; 95\% CI=15.3-27.3) had isolated abnormalities in serum potassium. The frequency of hypokalemia and hyperkalemia were $8.5 \%$ (95\% CI= 4.4-12.6) and $10.6 \%(95 \% \mathrm{CI}=6.1-15.1)$, respectively (Table 3). The hypokalemia was severe $(<2.5 \mathrm{mmol} / \mathrm{L})$ in $2.1 \%$ of cases. The frequency of combined hyponatremia and hypokalemia was $2.1 \%$. The mean anion gap and effective osmolality were 18.6 $\pm 0.6(95 \% \mathrm{CI}=18.4-18.8)$ and $301.3 \pm 10.0 \mathrm{mOsm} / \mathrm{kg} \mathrm{H}$ O (95\% CI= 298.4-304.2), respectively. The mean time for resolution of ketoacidosis 
was $2.8 \pm 0.6$ days $(95 \% \mathrm{CI}=2.6-3.0)$. Of the 28 cases seen in UBTH, one $(3.4 \%)$ patient died and she was aged 15years with severe mixed electrolyte disturbances; hyponatremia (serum sodium $124 \mathrm{mmol} / \mathrm{L}$ ), hypokalemia (serum potassium $2.6 \mathrm{mmol} / \mathrm{L}$ ) and severe acidosis (serum bicarbonate $5 \mathrm{mmol} / \mathrm{L})$. In addition, she received intravenous fluid and treatment for suspected cerebral malaria before referral to UBTH. No death was recorded among the cases seen in LUTH.

\section{Table 1: Distribution of gender, age and presenting complaints among the subjects.}

\begin{tabular}{|c|c|c|}
\hline Parameter & Number & Percent \\
\hline \multicolumn{3}{|l|}{ Gender $(N=47)$} \\
\hline Male & 20 & 42.6 \\
\hline Female & 27 & 57.4 \\
\hline \multicolumn{3}{|l|}{ Age in years $(\mathbf{N}=47)$} \\
\hline Below 5 & 7 & 14.9 \\
\hline $5-10$ & 18 & 38.3 \\
\hline Above 10 & 22 & 46.8 \\
\hline \multicolumn{3}{|l|}{ Presenting complaints $(\mathrm{N}=47)$} \\
\hline Polyuria alone & 27 & 57.4 \\
\hline Polyuria plus polydipsia & 41 & 87.2 \\
\hline Nocturia & 28 & 59.6 \\
\hline Weight loss & 12 & 25.5 \\
\hline Breathlessness & 24 & 51.1 \\
\hline Abdominal pain & 11 & 23.4 \\
\hline Vomiting & 19 & 40.4 \\
\hline Anorexia & 13 & 27.7 \\
\hline Impaired consciousness & 25 & 51.2 \\
\hline
\end{tabular}

$* \mathrm{~N}=$ Total number of patients

Table 2: Mean serum sodium and potassium concentrations according to age, gender and admission blood glucose levels.

\begin{tabular}{|c|c|c|c|c|}
\hline Parameter & $\begin{array}{l}\text { Mean serum } \\
\text { Sodium }\end{array}$ & $95 \% \mathrm{CI}$ & $\begin{array}{l}\text { Mean serum } \\
\text { potassium }\end{array}$ & $95 \% \mathrm{CI}$ \\
\hline
\end{tabular}

\begin{tabular}{|c|c|c|c|c|}
\hline \multicolumn{5}{|c|}{ Age in years $(\mathrm{N}=47)$} \\
\hline Below $5(n=7)$ & $125.5 \pm 3.8$ & $122.7-128.3$ & $4.7 \pm 0.19$ & $4.6-4.8$ \\
\hline $5-10(n=18)$ & $133.5 \pm 3.1$ & 132.1-134.9 & $3.9 \pm 0.16$ & $3.8-4.0$ \\
\hline Above $10(n=22)$ & $137.0 \pm 2.7$ & $135.9-138.1$ & $5.5 \pm 0.18$ & $5.4-5.6$ \\
\hline \multicolumn{5}{|l|}{ Gender $(N=47)$} \\
\hline Male $(\mathrm{n}=20)$ & $132.8 \pm 2.6$ & 131.7-133.9 & $4.4 \pm 0.17$ & $4.3-4.5$ \\
\hline Female $(n=27)$ & $132.4 \pm 2.4$ & $131.5-133.3$ & $4.7 \pm 0.16$ & $4.6-4.8$ \\
\hline
\end{tabular}




\section{Admission BG level $\mathrm{mmol} / \mathrm{L}(\mathrm{N}=47)$}
Below $20(\mathrm{n}=4)$
$129.0 \pm 3.1$
$126.0-132.0$
$4.5 \pm 0.12$
$4.4-4.6$
20-30 ( $\mathrm{n}=16)$
$128.6 \pm 2.9$
$127.2-130.0$
$4.3 \pm 0.14$
$4.2-4.4$
Above $30(\mathrm{n}=27)$
$134.4 \pm 2.8$
$133.3-135.5$
$4.8 \pm 0.13$
4.7- 4.9

$* \mathrm{BG}=$ Blood glucose; $* * \mathrm{CI}=$ Confidence interval; $\mathrm{N}=$ Total number of patients; $\mathrm{n}=$ Number of patients in each subgroup

\section{Table 3: Frequency of abnormal serum sodium and potassium concentrations among 47 patients at point}

of hospitalization

\section{Type of electrolyte \\ Disturbance}

Number

Hyponatremia

Hypernatremia

Severe hyponatremia

Hypokalemia

Hyperkaliemia

Severe hypokalemia

Hyponatremia plus

hypokalemia

Total

\begin{tabular}{ll}
12 & 25.5 \\
1 & 2.1 \\
1 & 2.1 \\
4 & 8.5 \\
5 & 10.6 \\
1 & 2.1 \\
1 & 2.1 \\
25 & 53.5 \\
\hline
\end{tabular}

\section{Discussion}

We found that at the point of admission in our paediatric emergency departments, slightly over half of the patients with new-onset diabetes complicated by ketoacidosis had abnormalities of serum sodium and potassium. Comparison was not possible because we could not find any report of a similar study. In a study in Karachi, Pakistan $17.9 \%$ of patients with DKA were found to have abnormalities in serum sodium and potassium during treatment (22). However, the authors did not state the prevalence rates of these electrolyte abnormalities at point of admission. Our study was different in that we studied the prevalence at point of admission before initiation of fluid resuscitation and insulin therapy. Despite this difference, the report of that study suggested that abnormalities of serum sodium and potassium may have been present at point of hospitalization. Also, in that study the authors stated that the biochemical complications were more frequent in children with newly diagnosed type
1 diabetes than in those with established diabetes (22).

Data from the present study revealed that disturbances in serum sodium was 2.5 times more frequent than disturbances in serum potassium. An explanation for this finding may be found in the report of Dunger at al regarding sodium and potassium losses in DKA (23). In that report, sodium losses $(5-13 \mathrm{mmol} / \mathrm{L})$ per kilogram body weight was greater than the losses for potassium $(3-6 \mathrm{mmol} / \mathrm{L})(23)$. A decline in serum sodium is a well-known osmoregulatory response to hyperglycemia (5). The frequency of isolated hyponatremia $(25.5 \%)$ in our study was comparable to $32.8 \%$ reported from Indonesia (24) but three times greater than that reported from Kenya (2). The higher frequency found in our study may be explained by differences in study population. We studied children with hyperglycemia complicated by ketoacidosis whereas the Kenyan study involved only children with hyperglycemia and no ketoacidosis. The frequency of hypernatremia found in the 
present study was 3-fold lower than $7.0 \%$ reported in a prospective among children with DKA (25). The report of a retrospective study from Children's hospital in Alabama, USA revealed that $33.0 \%$ of patients with DKA had hypernatremia (11).

The reason for the wide difference in prevalence of hypernatremia is not clear. It is possible that it is related to study design. Our study was retrospective whereas the other study was prospective (25) and cutoff for hypernatremia was $149 \mathrm{mmol} / \mathrm{L}$ in Monroe et al study (11). We applied a slightly higher cutoff of above $150 \mathrm{mmol} / \mathrm{L}$ which may have resulted in our lower prevalence. In the presence of hyperglycemia, an elevated serum sodium concentration indicates a clinically significant deficit in total body water (8). With regard to serum potassium, onefifth $(21.3 \%)$ of all our patients had isolated abnormal serum potassium concentration with a hyperkalemic prevalence rate of $10.6 \%$. The frequency of hyperkaliemia in the present study was lower than the frequency $(20.7 \%)$ reported in a study in Paskistan (24). The prevalence rate $(8.5 \%)$ of hypokalemia in the present study was comparable to $8 \%$ reported from Pakistan (17) but lower than $13.8 \%$ reported in a study in China (26).

The reason for the difference in prevalence rates at presentation between our patients and those from China is not clear. The implication in clinical practice is that more attention should be paid to serum potassium at presentation as well as during treatment of DKA to avoid precipitating a dangerously low serum potassium levels following initiation of insulin therapy. According to Beigelman, profound hypokalemia, even if transient, could be dangerous or prove fatal (19).

In addition, Murthy et al have also emphasized the therapeutic challenges posed by profound hypokalemia at presentation in the management of DKA (16). We found severe hypokalemia in $2.1 \%$ of cases. This was in keeping with 2.3\% reported from Pakistan (17). Although our prevalence of severe hypokalemia was low, it could prove fatal, if not recognized prior to initiation of insulin therapy. Other investigators have expressed a similar opinion $(15,16)$. Thus, reinforcing the recommendations of $\mathrm{ADA}$ and ISPAD concerning obtaining serum potassium values before initiation of insulin therapy $(3,4)$.

One of our patients had simultaneous co-existence of hyponatremia and hypokalemia. This is surprising because previous reports from Japan indicated an inverse relationship between serum sodium and potassium in DKA $(27,28)$.

Generally speaking, co-existence of hyponatremia and hypokalemia are suggestive of diuretic-induced hyponatremia. The subjects in the present study were not on any diuretic medication. Is it possible that the osmotic diuresis secondary to glycosuria is responsible for this finding the index patient with hyponatremia and hypokalemia was the only mortality (case fatality $3.4 \%$ ) recorded in this study in addition, she had severe acidosis (serum bicarbonate $5 \mathrm{mmol} / \mathrm{L}$ )? Together, these mixed electrolyte derangements may point to a more severe metabolic disturbance. Our case fatality rate was comparable with 3.4\% reported from Pakistan (17).

Although not a primary objective of the present study, we determined the anion gap and noted the clinical presentation of DKA in toddlers. In the present study, the mean anion gap was lower than 30.2 28.6 reported from Riyadh, Saudi Arabia (29). The reason for the difference is not immediately obvious. This finding may suggest that children presented with more severe disease in Saudi Arabia compared to Nigeria. The clinical implication needs to be determined in future studies. The mean time for resolution of ketoacidosis in our patients was comparable to 48-72 hours reported by Lone et al, among new-onset DKA in Pakistan (22). In that study they showed that the time of resolution of DKA was shorter in established diabetes than in new-onset diabetes (22). In another study in Pakistan, the mean time of resolution ketoacidosis was $19.1 \pm 19.5$ hours (17).

However, the subjects included patients with established diabetes. Thus, accounting for their shorter time compared to our study. The presenting complaints in toddlers differed from those of older children. In this regard, polyuria, weakness and anorexia were more prominent in toddlers than in older children. This is similar to the reports of other researchers $(30,31)$. Therefore, physicians should remain vigilant and maintain a high index of suspicion for DKA in toddlers because classical presenting complaints may be absent in them coupled with the fact that they may not verbalize their complaints to the caregivers.

In conclusion, at point-of-admission disturbances in serum sodium and potassium concentrations were common in paediatric new-onset diabetes with ketoacidosis. Polyuria, weakness and anorexia were the key presenting complaints in toddlers with DKA. 
1. Liamis G, Rodenburg EM, Hofman A, Zietse R, Stricker BH. Electrolyte disorders in community subjects: prevalence and risk factors. Am J Med 2013; 126:256-263.

2. Ibinda F, Zarnack H, Newton CR. Sodium disturbances in children admitted to the Kenyan hospital: magnitude, outcome and associated factors. PLOS ONE 2016;11(9): e0161320

3. Kitabchi AE, Umpierrez GE, Murphy MB, Kreisberg RA. Hyperglycemic crises in adult patients with diabetes. Diabetes Care 2006; 29:2739-2748.

4. Wolfsdorf JI, Allgrove J, Craig ME, Edge J, Glaser N, Jain V, Lee WWA, Mungai LNW, Rosenbloom AL, Sperling MA, Hanas R. Consensus statement from International Society for Pediatric and Adolescent Diabetes: Diabetic ketoacidosis and hyperglycemic hyperosmolar state. Pediatric Diabetes 2014;15(Suppl 20):154-179.

5. Liamis G, Liberopoulos E, Barkas F, Ellisaf M. Diabetes mellitus and electrolyte disorders. World J Clin Cases 2014;2(10):488-496.

6. Sweeney G, Klip A. Regulation of the Na+/K+-ATPase by insulin: why and how? Mol Cell Biochem 1998; 18:121-133.

7. Beukhof CM, Hoorn EJ, Lindemans J, Zietse R. Novel risk factors for hospital-acquired hyponatremia: a matched casecontrol study. Clin Endocrinol (Oxf) 2007; 66:367-372.

8. Palmer BF, Clegg DJ. Electrolyte and acid-base disturbances in patients with diabetes mellitus. N Engl J Med 2015; 373:548-559.

9. Singhal PC, Abramovici M, Ayer S, Desroches L. Determinants of rhabdomyolysis in the diabetic state. Am J Nephrol 1991; 11:447-450.

10. Bialo SR, Agrawal S, Rare complications of paediatric diabetic ketoacidosis. World J Diabetes 2015;6(1):167-174.

11. Monroe KW, King WD, Nichols MH, Atchison JA. Hypernatremia in diabetic ketoacidosis. Pract Diabetes Int 1997;14(6):159-161.

12. Arora S, Cheng D, Wyler B, Menchine M. Prevalence of hypokalaemia in emergency department patients with diabetic ketoacidosis. Am J Emerg Med 2012; 30:481-484.

13. Kanwal SK, Bando A, Kumar V. Clinical profile of diabetic ketoacidosis in Indian children. Indian J Pediatr 2012; 79:901904.

14. McDonough AA, Thompson SB, Youn JH. Skeletal muscle regulates extracellular potassium. Am J Physiol 2002;282: F967-F974.

15. Davis SM, Maddux AB, Alonso GT, Okada CR, Mourani PM, Maahs DM. Profound hypokalaemia associated with severe diabetic ketoacidosis. Pediatr Diabetes 2016;17(1):61-65.

16. Murthy K, Hamington JT, Siegel RD. Profound hypokalemia in diabetic ketoacidosis: a therapeutic challenge. Endocr Pract 2005; 11:331-334.

17. Syed M, Khawaja FB, Saleem T, Khalid U, Rashid A, Humayun KN. Clinical profile and outcomes of paediatric patients with diabetic ketoacidosis at a tertiary care hospital in Pakistan. J Pak Med Assoc 2011; 61:1082-1087.

18. Orban J-C, Maiziere E-M, Ghaddab A, Van Obberghen E, Ichai C. Incidence and characteristics of acute kidney injury in severe diabetic ketoacidosis. PLoS ONE 2014;9(10): e110925.

19. Beigelman PM. Potassium in severe diabetic ketoacidosis. Am J Med 1973;54(4):419-420 [Editorial].

20. Gleiberman L. Sodium, blood pressure and ethnicity: what have we learned? Am J Hum Biol 2009; 21:679-686.

21. Suh A, DeJesus E, Rosner K, Lerma E, Yu W, Young JB, Rosa RM. Racial differences in potassium disposal. Kidney Inter 2004; 66:1076-1081.

22. Lone SW, Siddiqui EU, Muhammed F, Atta I, Ibrahim MN, Raza J. Frequency, clinical characteristics and outcome of diabetic ketoacidosis in children with type 1 diabetes at a tertiary care hospital. J Pak Med Assoc 2010; 60:725-729.

23. Dunger DB, Sperling MA, Acerini CL, Bohn DJ, Daneman D, Danne TP, Glaser NS, Hanas R, Hintz RL, Levitsky LL, Savage MO, Tasker RC, Wolfsdorf JI, ESPE, LWPES. ESPE/LWPES consensus statement on diabetes ketoacidosis in children and adolescents (Review). Arch Dis Child 2004; 89:188-194.

24. Rochmah N, Faizi M, Harjantien N, Diabetic ketoacidosis in children: an 11-year retrospective in Surabaya Indonesia. Paediatr Indones 2015;55(1):40-43. 
25. Harris G, Fiordalisi I. Physiologic management of diabetic ketoacidosis: a five-year prospective pediatric experience in 231 episodes. Arc Pediatr Adolesc Med 1994; 148:1046-1052.

26. Lee KL, Ko CH, Lee CY, Hung CN, Fong NC, Yiu WL. Prevalence and potential risk factors of hypokalemia in pediatric patients with diabetic ketoacidosis. Inter J Pediatr Endocrinol 2015;(Suppl 1):8 [Poster Presentation.]

27. Ishikawa S, Sakuma N, Fujissawa G, Tsuboi Y, Okada K, Saito T. Opposite changes in serum sodium and potassium in patients in diabetic coma. Endorr J 1994; 41:37-43.

28. Saito T, Ishikawa S, Higashiyama M, Nakamura T, Rokkaku K, Hayashi H, Kusaka I, Nagasaka S, Saito T. Inverse distribution of serum sodium and potassium in uncontrolled in-patients with diabetes mellitus. Endocr J 1999;46(1):7580.

29. Almalki MH, Buhary BM, Khan SA, Almaghamsi A, Alshahrani F. Clinical and biomedical characteristics of diabetic ketoacidosis in tertiary hospital in Riyadh. Clin Med Insights Endocrinol Diabetes 2016; 9:7-11.

30. Katte J, Djoumessi R, Njindam G, Fetse GT, Dehayem M, Kengue A. New-onset diabetic ketoacidosis in a 13-monthold African toddler: a case report. Pan Afr Med J 2015; 22:293-295.

31. Kotori VM, Gashi N, Toro H. Severe ketoacidosis at onset of type 1 diabetes in children due to late diagnosis. Diabetologia Croatia 2007;36(3):59-65. 